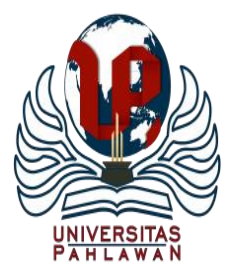

Edukatif : Jurnal Ilmu Pendidikan Volume 3 Nomor 1 Tahun 2021 Halm 66 - 74 EDUKATIF: JURNAL ILMU PENDIDIKAN

Research \& Learning in Education

https://edukatif.org/index.php/edukatif/index

\title{
Pembelajaran Keterampilan Motorik
}

Yufa Ficanysha $^{1 \bowtie}$, Neviyarni $^{2}$

Universitas Negeri Padang, Sumatera Barat, Indonesia ${ }^{1,2}$

E-mail : ficanyshayufa08@gmail.com ${ }^{1}, \underline{\text { neviyarni.suhaili911@ @mail.com }}^{2}$

\begin{abstract}
Abstrak
Manusia adalah makhluk hidup yang mempunyai sifat dasar dinamis, dimana sifat dinamis tersebut menghasilkan ciri khusu setiap individu yang selalu mengalami aktivitas pergerakan. Dalam pertumbuhan aktivitas gerak yang terjadi pada seluruh manusia sejak umur bayi hingga dewasa, proses perkembangan gerak yang dialami akan melalui beberapa tahapan secara berkala. Antara individu yang satu dengan individu lainnya, terdapat perbedaan pada proses perkembangan gerak. Selain proses yang berbeda, pertumbuhan gerak manusia juga dapat dikategorikan menjadi beberapa bagian. Dalam pengertian sederhana, hal ini berarti seluruh aktivitas gerak yang dialami oleh manusia merupakan gerak motorik. Sistem sara, otak, serta otot dapat mempengaruhi gerak motorik. Keterampilan gerak seorang individu yang merupakan dampak dari pembelajaran dapat diartikan sebagai keterampilan motorik, Keterampilan ini berkaitan erat dengan faktor pembawa. Pembelajaran keterampilan motorik memiliki peranan yang penting pada sejarah manusia.
\end{abstract}

Kata kunci: belajar, keterampilan motorik

\begin{abstract}
Humans are living creatures that have a dynamic nature, which this dynamic nature gives a characteristic to humans themselves by always taking action in motion. In the development of movements experienced by each individual from the process of infant age to adulthood, the process of developing motion that occurs will undergo several gradual processes. And the process of developing this movement has differences between one individual and another. Apart from different processes, the development of human movement is also divided into several parts. Where in a simple sense, all movements carried out by humans are motoric movements. Motor movement is influenced by muscles, brain, and nerves. Motor skills can be defined as the movement skills of a person from learning outcomes, many motor skills are innate, the learning of motor skills has played a big role in human history.
\end{abstract}

Keywords: motoric skill learning

Copyright (c) 2021 Yufa Ficanysha, Neviyarni

$\triangle$ Corresponding author

Email : jakaamrin799@gmail.com

DOI : https://doi.org/10.31004/edukatif.v3i1.180

ISSN 2656-8063 (Media Cetak)

ISSN 2656-8071 (Media Online) 


\section{PENDAHULUAN}

Perkembangan motorik atau gerak pada masa pertumbuhan anak memili peranan yang mendasar serta penting untuk keberlangsungan pertumbuhan serta perkembangan seorang anka sampai menjadi dewasa. Secara natural sejalan dengan bertambahnya usia anak sampai menjadi dewasa akan di ikuti dengan kenaikan kapabilitas motorik kasar anak. Keterampilan adalah ilustrasi kapabilitas motorik seorang individu yang ditandai melalui keahlian pada satu jenis gerak (Rahyubi, 2012). Kapabilitas motorik anak bisa bertumbuh dengan baik serta pesat jika anak memili aktivitas gerak yang beraneka ragam. Saat mempelajari keterampilan motorik biasanya dengan diberikan stimulus. Dengan mengamati orang lain berlatih dan belajar tugas motorik meningkatkan perolehan keterampilan, yang mungkin diakibatkan oleh melibatkan pengamat dalam proses kognitif yang khas dari proses pembelajaran. Efek dari mengamati model pembelajaran, dan mendukung gagasan bahwa satu penyebab mendasar akselerasi akuisisi dan retensi ini adalah keterlibatan dalam proses kognitif yang menjadi ciri tahap awal keterampilan belajar (Hebert, 2018: 7).

Pembelajaran motorik sebagai upaya untuk meningkatkan keterampilan motorik yang diakibatkan oleh situasi-situasi latihan atau didapatkan dari pengalaman, namun tidak berasal dari proses pendewasaan atau perubahan fisiologis dan motivasi sementara (Rahantoknam,1988). Sekolah merupakan salah satu cara menyelenggarakan sistem pendidikan nasional, agar bisa memfasilitasi pendidikan dasar untuk seluruh warga negara Republik Indonesia. Manusia merupakan makhluk yang berdiam di bumi serta bersifat fenomenal. Dibandingkan dengan mahkluk lainnya, manusia diciptakan dengan banyak keistimewaan. Pada pembelajaran keterampilan motorik tugas kita ialah memverbalisasikan keterampilan dan mencoba mengidentifikasikan komponen bagian-bagiannya. Pada pembelajaran ini perlu adanya latihan pada komponen tertentu, dimana saat kompleksitas tugas-tugas meningkat, maka kita memfokuskan latihan pada komponen tugas tertentu yang khusus. Umpan balik merupakan faktor yang penting dalam mencapai hasil tampilan keterampilan motorik yang bermanfaat untuk mengevaluasi tampilan keterampilan motorik dan membandingkannya dengan tampilan standar. Latihan pada pembelajaran ketrampilan motorik juga perlu dilakukandi bawah kondisi yang bervariasi, karena memori kita juga membutuhkan variasi-variasi stimulus. Terakhir, kelancaran keterampilan motorik memerlukan latihan terus menerus.

\section{METODE PENELITIAN}

Artikel ini membahas tentang analisis tahapan dalam pembelajaran keterampilan motorik, jenis metode penelitian ini merupakan analisa kajian pustaka (literatur research) artikel ini akan membahas analisis jurnal ilmiah yang relevan dengan pokok bahasan yang telah dipilih, adapun langkah-langkah pada metode penelitian ini yakni (1) memilih artikel, (2) mengumpulkan data awal, (3) hambatan dari topik, (4) mengumpulkan data pendukung, (5) menarik kesimpulan serta rekomendasi online.

\section{HASIL DAN PEMBAHASAN PENELITIAN}

\section{A. Defenisi Belajar Keterampilan Motrik}

Belajar keterampilan motorik merupakan proses pembelajaran yang menggunakan perseptual dan mengolahnya menjadi tindakan motorik, yang mana kegiatan belajar merupakan suatu proses yang berurutan dari kegiatan penginderaan kemudian diaplikasikan dengan keterampilan. Belajar keterampilan motorik mengacu pada semua kegiatan di mana proses belajar menghendaki suatu urutan respon motorik tubuh (motor responses) secara tepat.

Setiap individu senantiasa menjalani proses pembelajaran dalam hidupnya, proses belajar dapat menuntun seseorang dalam melakukan perubahan pada kualitas dirinya (Mulyani, D, 2013). Belajar 
merupakan suatu kegiatan yang dilakasanakan dengan secara sengaja guna memperoleh sejumlah kesan dari bahan yang sudah mengalami perubahan pada seseorang sebaiknya, jika tidak terdapat perubahan pada seseorang, proses pembelajaran dikategorikan tidak berhasil ( Putri D. Selpia dan Neviyarni. S, 2013).

Menurut (Henry C. Ellis (1978:277) belajar keterampilan motorik merupakan proses pembelajaran yang menggunakan perseptual dan mengolahnya menjadi tindakan motorik, yang mana kegiatan belajar merupakan suatu proses yang berurutan dari kegiatan penginderaan kemudian diaplikasikan dengan keterampilan. Belajar keterampilan motorik mengacu pada semua kegiatan di mana proses belajar menghendaki suatu urutan respon motorik tubuh (motor responses) secara tepat.

Senada dengan hal tersebut Zulkifli (Samsudin, 2008) motorik adalah segala sesuatu yang ada hubungannya dengan gerakan-gerakan tubuh. Motorik dapat dikatakan sebagai kegiatan yang melibatkan otot-otot sehingga terjadi suatu gerakan dari tubuh. Keterampilan motorik merupakan kemampuan atau kecakapan seseorang untuk menunjukkan gerakan tubuh secara cepat dan akurat. Keterampilan motorik tersebut merupakan suatu keterampilan umum seseorang yang berkaitan dengan berbagai keterampilan atau tugas gerak. Menurut (Yudrik Jahja, 2012:28) Perkembangan motorik merupakan proses tumbuh kembang kemampuan gerak seseorang. Jadi, setiap gerakan yang dilakukan oleh seseorang merupakan hasil pola interaksi yang kompleks dari berbagai bagian dari sistem dalam tubuh yang dikontrol oleh otak. Keterampilan belajar telah memiliki peran utama dalam perkembangan sejarah manusia. Bahkan perkembangan dunia secara global di dasari oleh keterampilan yang dimiliki. Melalui perkembangan teknologi modern abad 20, sebelumnya skill di anggap kurang penting, sebaliknya baru - baru ini skills sudah menjadi sesuatu yang sangat penting. Karena kecenderungan manusia yang berubah seperti cara kerja manusia saat ini memerlukan skills.

Hurlock (dalam Lutan, R : 1988 )Keterampilan Motorik berarti perkembangan pengendalian gerakan fisik melalui kegiatan syaraf dan otot yang terkoordinasi. Istilah keterampilan motorik dan perseptual motor skill sering digunakan secara bergantian, karena maknanya dianggap sama. Disamping penerbangan dan mengemudi, keterampilan para atletik lebih membutuhkan koordinasi tentang perilaku motorik melalui stimulus yang diberikan. Seperti bermain tenis meja, badminton, bola kaki, dll. Sehingga pembelajaran keterampilan motorik sering juga disebut dengan belajar persepsi motorik dan belajar keterampilan motorik mengacu pada akuisisi dari urutan-urutan respon motorik secara tepat. Dalam pembelajaran motorik lebih ditekankan kepada pembelajaran keahlian gerakan yang bisa langsung digerakan oleh anggota tubuh atau bahkan seluruh anggota tubuh. Akan tetapi semua gerakan tersebut dapat berfungsi sesuai kematangan dan pengendalian gerak tubuh Decaprio (2017:14).

Drowaztky (1981) menjelaskan bahwa pembelajaran motorik merupakan proses belajar yang dilaksanakan lewat stimulus-stimulus muskuler yang umumnya di ekspresikan dengan pergerakan pada bagian tubuh. Oxendine (1984) juga menjelaskan bahwa pembelajaran motorik merupakan suatu prosedur yamng menghasilakn perubahan dengan sifat tetap pada sikap motorik sebagai hasil dari pengalaman serta latihan. Schmidt (1988) mengatakan bahwa pembelajaram motorik merupakan serangkaian prosedur yang memili kaitan dengan pengalaman atau Latihan yang menghasilkan perubahan secara tetap pada sikap terampil.

\section{B. Kajian Belajar Keterampilan Motorik}

Kajian tentang keterampilan motorik membedakan keterampilan ini menjadi dua jenis. Pertama, keterampilan motorik continius response, yaitu keterampilan motorik yang menghendaki gerak secara terus menerus. Kedua, keterampilan motorik discrete response, yakni dilakukan dengan interval antara setiap respon. Contoh untuk kedua jenis ini adalah pada atlit yang sedang bermain bola kaki. Berlari 
selama bermain di lapangan adalah keterampilan motorik continius response, sedangkan menendang bola adalah keterampilan motorik discrete response. Contoh lain adalah pada pengemudi mobil, mengendarai mobil memerlukan keterampilan motorik continius response, sedangkan menginjak rem, memutar stir memerlukan keterampilan motorik discrete response. Pembelajaran tentang belajar keterampilan motorik, membedakan keterampilan dalam dua jenis, yaitu:1) keterampilan motorik yang menghendaki gerak secara terus menerus dan 2) keterampilan motorik yang dilakukan dimana terdapat interval/ jarak antara setiap respon. Contoh dari kedua jenis keterampilan ini dapat dilihat pada atlit yang bermain bola kaki. Berlari selama bermain di lapangan adalah keterampilan motorik yang menghendaki respon secara terus menerus, sedangkan menendang bola adalah keterampilan motorik dimana terdpat jarak antara respon.

\section{Karakteristik Belajar Keterampilan Motorik}

Ada empat unsur fundamental dari tampilan (performance) keterampilan. (1) Tampilan keterampilan yang melibatkan suatu urutan respon motorik, (2) yang memerlukan koordinasi input perseptual dengan respon motorik, (3) melibatkan pengaturan urutan respon, dan (4) ketergantungan yang kuat pada umpan balik (feedback).

Ada empat unsur pokok karateristik keterampilan motorik, yaitu: 1) response sequences (respon berurut) dimana setiap respon berperan sebagai stimulus untuk respon berikutnya. 2) perceptual motor coordination, semua gerakan dilakukan dengan cara melihat stimulus yang datang. 3) respon organization),keterampilan dilakukan dengan mengatur dan menggorganisasikan respon dalam sebuah pola umpamanya pada saat kita berenang. Kita dapat membagi bentuk gerak ke dalam beberapa bentuk gerak kedalam beberapa sub-gerak. Setiap gerakan menerima penekanan tertentu gerakan tangan pernafasan, gerakan kaki merupakan sub - gerak yang merupakan rantai respon yang diatur sedemikian rupa sehingga menjadi proses berenang. Pengukuran dan pola keterampilan motorik ini dari faktor sementara dan ssebagian (spatial). 4) feedback,tampilan keterampilan motorik memerlukan umpan balik balik intrinsik, yaitu kenyataan bahwa respon menghasilkan stimulus yang menyebabkan timbulnya respon berikutnya.

a) Respon berurut

Dalam tampilan keterampilan yang melibatkan suatu respon motorik berurut setiap respon berperan sebagai stimulus untuk respon berikutnya. Umpamanya mengenakan tali sepatu, setelah memasukkan tali ke dalam lubang, kita menarik tali, respon menarik tali itu menjadi stimulus untuk respon menyilangkan tali, dan seterusnya.

b) Koordinasi perseptual motorik

Dalam keterampilan yang memerlukan koordinasi perseptual motorik, umpamanya dalam permainan bola voli, bila bola melambung dekat net, maka respon pemain adalah melakukan pukulan smash.

c) Pengaturan respon

Pada bentuk tampilan ini keterampilan dilakukan dengan mengatur dan mengorganisasikan respon ke dalam sebuah pola. Umpamanya, pada saat kita berenang, kita dapat membagi bentuk gerak ke dalam beberapa sub-gerak. Setiap gerakan menerima penekanan tertentu.

d) Umpan balik

Tampilan keterampilan motorik yang memerlukan umpan balik sangat tergantung pada umpan balik instrinsik. Umpan balik instrinsik adalah kenyataan bahwa respon menghasilkan stimulus yang menyebabkan timbulnya respon subsequent. 


\section{Fase Belajar Keterampilan Motorik}

Meskipun belajar keterampialn motorik merupakan proses yang berkesinambungan, namun ahli psikologi membedakan belajar keterampilan motorik ini dalam tiga fase. Hal ini di dasarkan menurut Paul Fitts ada tiga tahap dalam belajar keterampilan motoric (dalam Henry C. Ellis, 1978: 230-232) yaitu:

1. Fase Kognitif

Ini merupakan tahap yang paling pertama sekali dilakukan. Pada fase ini individu berusaha memahami apa yang diharapkan dari dirinya. Dalam hal ini individu berusaha memahami, memverbalisasikan, dan mengintelektualisasikan keterampilan yang akan dipelajari dengan cara mengkonsepkan komponen-komponen tugas-tugas tersebut. Contoh: Dalam mengajar pengucapan vokal yang tepat, konsonan, diptong, dan kata-kata. Pertama, guru mengajarkan kepada siswa tentang bagaimana membuat suara atau bunyi tertentu. Ini dilakukan dengan cara menyampaikan kepada siswa posisi lidah. Kedua siswa mulai mengucapkan kata "colour". Namun dalam hal ini siswa masih mencoba-coba, jadi tak jarang terkadang siswa salah dalam menngucapkana dan kembali belajar.

2. Fase Asosiasi

Dalam hal ini asosiasi respon yang dipelajari menjadi terintegrasi sebagai suatu rantai yang sangat efesien. Ini ditandai dengan semakin efektif cara-cara siswa melaksanakan tugas gerak, dan siswa mulai menyeseuaikan diri dengan keterampilan yang dilakukan. Tahap ini dimana ia mirip dengan tahap asosiatif pada belajar verbal, karena pada intinya sama asosiatif. Contoh: Dalam belajar mengemudi mobil, seseorang tidak hanya berpikir tentang pola gerakan mengemudi yang berurutan saja, tetapi individu mulai mempertimbangkan antara kecepatan dan struktur jalan yang sesuai. “apabila di jalan lurus seperti apa, jalan yang berkelok-kelok seperti apa", dll.

3. Fase Autonomi

Pada tahapan ini tampilan motorik lebih menjadi efesien sehingga dapat kita lakukan secara yang otomatis. Kecepatan keterampilan motorik semakin meningkat sehingga secara terus menerus memperkuat pola respon baru dan hal ini bukan hanya karena pengulangan respon yang sama. Pada tahap akhir keterampilan motorik semakin tahan terhadap gangguan yang mungkin dapat merusak keterampilan tersebut. Contoh dari tahap asosiatif ini adalah melakukan tugas pengetikan.Orang bisa melakukan pengetikan tanpa harus melihat keyboard. Tahap terakhir dari pembelajaran ketrampilan motorik, tahap autonomous, merupakan tahap dimana penampilan ketrampilan akan menjadi lebih efesien sehingga ia dapat dikerjakan secara lebih otomatis. Kecepatan penampilan ketrampilan semakin meningkat karena ia terus menerus memperkuat pola respon baru, dan ini bukan semata-mata karena proses pengulangan respon yang sama. Pada tahap terakhir ini, penampilan ketrampilan menjadi semakin semakin kebal terhadap gangguan yang merusak ketrampilan tersebut. Seorang pengetik yang sudah sangat mahir tidak terpengaruh oleh suara radio atau yang lain, bahkan ia sendiri mampu mengetik sambil berbicara dengan orang lain Schmidt (1988).

\section{E. Faktor-faktor yang Mempengaruhi Belajar Keterampilan Motorik}

Sebagaimana jenis belajar lainnya, belajar keterampilan motorik tergantung karakteristik tugas dan orang yang belajar. Faktor yang mempengaruhi keterampilan belajar motorik adalah:

1) Umpan balik

Salah satu faktor yang mempengaruhi belajar keterampilan motorik adalah umpan balik (feedback), yang terdiri dari dua jenis: pertama, umpan balik instrinsik yang merupakan informasi yang diterima untuk melakukan tampilan keterampilan motorik pada suatu latihan tertentu. Kedua, umpan 
balik ekstrinsik yang merupakan suatu knowledge of result yang menekankan ciri informal dari umpan balik.

a) Pentingnya Umpan balik

Umpan balik sangat penting dalam belajar keterampilan motorik. Umpan balik diperlukan untuk mempengaruhi tampilan keterampilan motorik Tanpa adanya umpan balik maka orang yang belajar merasa tidak ada keberhasilan bahwa ia telah menguasai suatu keterampilan motorik. Umpan balik menjadi acuan bagi individu dalam melihat perkembangannya dalam belajar. Umpan balik yang bersifat kuantitatifdapat menggambarjkan kepada indiidu bahwa ia telah memiliki keterampilan motorik yang lebih baik daripada yang lainnya.

b) Penghilangan Umpan balik dan Reinforcement Subjektif

Penghilangan atau pengambilan kembali umpan balik berpengaruh terhadap tampilan keterampilan motorik, tetapi pengaruhnya tidak seperti penghilangan reinforcement pada belajar instrumental. Penghilangan umpan balik pada belajar keterampilan motorik dapat mengakibatkan penurunan tampilan secara bertahap, namun tidak sampai pada tingkat tampilan ketika awal latihan. Penghilangan umpan balik akan berpengaruh terhadap tampilan keterampilan motorik. Tetapi pengaruh yang ada tidak seperti pada penghilangan reinforcementpada belajar instrumental. Penghilangan ini dapat mengakibatkan penurunan tampilan secara bertahap, namun tidak sampai pada tingkat tampilan yang sedang berlangsung. Jika tingkat latihan rendah atau sedang, penghilangan umpan balik mengakibatkan pengaruh penurunan terhadap tampilan. Namun setelah latihan dikembangkan lagi, sering tidak terjadi penurunan tingkat keterampilan.

c) Penundaan Umpan balik

Bentuk umpan balik lainnya adalah umpan balik yang diberikan dengan penundaan waktu antara respon subyek (si pelajar) dan umpan balik informatif. Penundaan umpan balik ternyata tidak mempengaruhi perolehan beberapa bentuk keterampilan motorik. Penundaan umpan balik yang disebut postfeedback berpengaruh sangat besar terhadap tampilan. Yang dimaksud postfeedback adalah interval antara umpan balik dengan latihan pada awal latihan berikutnya. Penundaan umpan dapat berupa penundaan waktu antara respon subjek dan umpan balik informatif. Penundaan ini ternyata tidak mempengaruhi perolehan beberapa bentuk keterampilan motorik. Namun menyebabkan penurunan serius dalam tampilan pelaksanaan latihan yang membutuhkan kegiatan secara terus menerus, misalnya pada saat mengemudi.Penundaan umpan balik sebaiknya dilakukan seminimal mungkin.

2) Distribusi Latihan

Selain itu, distribusi latihan membantu perolehan keterampilan motorik. Respon yang didistribusikan merupakan sisa interval selama proses perolehan keterampilan motorik, sedangkan massed practice hampir sama dengan tampilan keterampilan motorik yang berkelanjutan atau terus menerus. Pelaksanaan latihan yang dilakukan secara terdistribusi akam membantu perolehan keterampilan motorik. Keterampilan motorik juga dipengaruhi oleh factor stress dan kelelahan. Stres dapat didefinisikan dengan dua cara, yaitu: (1) merupakan keadaan dimana organisme dalam keadaan termotivasi atau emosional, yang disebut juga dengan tekanan emosi, (2) beban/ tuntutan pekerjaan pada individual, bila anda diharuskan mengikuti beberapa peristiwa sementara anda harus menyelesaikan suatu tugas/pekerjaan lainnya, maka anda akan mengalami stress yang lebih berat. Kedua definisi ini sebenarnya memiliki infomasi yang saling tumpang tindih. Jika stress meningkat, tampilan keterampilan motorik meningkat sampai pada titik normal dan penurunan stress akan mengurangi tampilan 


\section{3) Stres dan Kelelahan}

Stres dapat didefinisikan dengan dua cara. Pertama, ia merupakan keadaan di mana organisme (manusia) dalam keadaan termotivasi dan/atau emosional, yang sering juga disebut dengan tekanan emosi. Kedua stres didefinisikan sebagai permintaan tugas/pekerjaan pada seseorang. Bila anda diharuskan mengikuti beberapa peristiwa sementara anda harus menyelesaikan suatu tugas/pekerjaan lainnya maka anda akan mengalami stress yang lebih berat dari pada jika anda menyelesaikan satu tugas saja. Definisi yang kedua ini disebut juga information overload. Jika stress meningkat, tampilan keterampilan motorik meningkat sampai pada titik optimal dan penurunan stres akan mengurangi tampilan.

\section{F. Teori Belajar Keterampilan Motorik}

Secara tradisional belajar motorik dipandang identik dengan proses belajar instrumental. Pandangan ini berasal dari anggapan bahwa dalam karakteristik belajar motorik sama dengan belajar instrumental, yang tergantung pada pengaruh hukum klasik. Belajar motorik menuntut subyek yang belajar melakukan serangkaian respon gerak yang mana terpisah-pisah, yang masingmasignya diikuti oleh respon bebentuk pengetahun atau umpan balik. Schmidt (1988:34) menegaskan bahwa belajar gerak merupakan suatu rangkaian asosiasi latihan atau pengalaman yang dapat mengubah kemampuan gerak ke arah kinerja keterampilan gerak tertentu.

Perkembangan pada akhir ini memandang bahwa pembelajaran motorik lebih dari sekedar belajar instrumental. Belajar motorik menekankan pada karakter pemecahan masalah dan proses kognitif. Jack Adams yang mengembangkan teori ini memandang bahwa belajar motoric dapat dikatakan sebuah teori yang ada unsur S-R (stimulus-respon) dan belajar kognitif. Dalam teori ini yaitu closed-loop teori yang penting. Gagasan dasar sistem closed-loop adalah bahwa respon memberikan umpan balik pada sistem, yang mana setelah itu kita membuat sistem itu memuncak pada kemampuan aturan diri kita.

\section{G. Beberapa Prinsip Praktis}

Beberapa prinsip praktis yang dapat kita simpulkan dari bahasan tentang keterampilan motorik. Pada pembelajaran keterampilan motorik tugas kita ialah memverbalisasikan keterampilan dan mencoba mengidentifikasikan komponen bagian-bagiannya. Pada pembelajaran ini perlu adanya latihan pada komponen tertentu, dimana saat kompleksitas tugas-tugas meningkat, maka kita memfokuskan latihan pada komponen tugas tertentu yang khusus. Umpan balik merupakan faktor yang penting dalam mencapai hasil tampilan keterampilan motorik yang bermanfaat untuk mengevaluasi tampilan keterampilan motorik dan membandingkannya dengan tampilan standar. Latihan pada pembelajaran ketrampilan motorik juga perlu dilakukandi bawah kondisi yang bervariasi, karena memori kita juga membutuhkan variasi-variasi stimulus. Terakhir, kelancaran keterampilan motorik memerlukan latihan terus menerus.

Prinsip praktis pertama yang dapat ditarik dari bahasan di atas adalah :

1) Understand the Task (Pemahaman Tugas). Dalam hal ini tugas kita adalah mem-verbalisasi-kan keterampilan, mencoba meng-identifikasi-kan komponen bagian-bagiannya.

2) Practice on Spesific Component(melakukan latihan pada komponen tertentu). Pada saat kompleksitas tugas-tugas meningkat, maka kita memfokuskan latihan pada komponen tugas tertentu yang khusus.

3) Obtain Feedback (Mendapatkan Umpan Balik). Baik instrinsik maupun ekstrinsik, karena umpan balik merupakan faktor penting dalam mencapai hasil tampilan keterampilan motorik. Umpan balik 
berguna untuk mengevaluasi tampilan keterampilan motorik dan membandingkannya dengan tampilan standar.

4) Practice Under Varied Conditions (melakukan latihan di bawah kondisi yang bervariasi). Melakukan latihan di bawah kondisi yang bervariasi karena hal ini membantu tampilan keterampilan motorik.

5) Sustain Practice(mempertahankan latihan). Mempertahankan latihan akan memperkuat kelancaran keterampilan motorik memerlukan latihan yang terus menerusAda beberapa teori yang menerangkan tentang keterampilan motorik. Menurut teori tradisonal, keterampilan motorik identik dengan pembelajaran instrumental. Menurut teori stimulus-respon yang dikembangkan oleh Jack Adam, keterampilan motorik menekankan kepada pemecahan masalah dan proses kognitif. Menurut teori closed loop, respon terhadap suatu sistem akan memberikan pengaruh terhadap system itu sendiri sehingga akan cenderung mengatur diri sendiri (self regulating).

\section{KESIMPULAN}

Pada masa pertumbuhan anak, perkembangan gerak atau perkembangan motorik sangatlah penting dan mendasar bagi kelanjutan perkembangan anak tersebut ke tahap selanjutnya. Secara alamiah seiring peningkatan atau bertambahnya umur anak hingga dewasa akan di ikuti dengan peningkatan kemampuan motorik kasar anak. Kemampuan motorik anak dapat tumbuh dan berkembang secara baik apabila anak mempunyai pengalaman gerak yang beraneka macamGerak merupakan aktivitas yang tidak dapat dipisahkan dalam kehidupan manusia. Dengan memiliki keterampilan motorik yang baik, maka dapat menunjang kehidupan sehari-hari. Keterampilan motorik dapat terjadi karena faktor pertumbuhan dan keadaan individu yang mengharuskan untuk bergerak. Oleh karena itu pemahaman dan implementasi untuk memberikan layanan kepada peserta didik dalam meningkatkan keterampilan motorik sangat penting. Dengan demikian keterampilan motorik merupakan salah satu faktor yang dapat menunjang kehidupan manusia di masa mendatang.

\section{DAFTAR PUSTAKA}

Drowatzky, John, N. 1981. Motor Learning Princples And Practice. Minneapolis: Burger Publishing Company

Decaprio, Richard, 2017. Panduan Mengembangkan Kecerdasan Motorik Siswa: Konsep dan Penerapan Teori Pembelajaran Motorik di S ekolah. DIVA Press : Yogyakarta.

Ellis, Henry C. 1978. Foundamentals Of Human Learning, Memory and Cognition (2nd Edition). Iowa: Wm. C. Brown Company Publisher

Henry C., Ellis, (1978), Fundamental of human Learning Memory and Cognition, Mexico, Mexico University.

Hebert, E. 2018. The Effects of Observing a Learning Model (or Two) on Motor Skill Acquisition. Journal of Motor Learning and Development, 6(1), 4-17

Jahja, Y. 2012. Psikologi Perkembangan. Jakarta: Kencana Prenada Media Group.

Lutan, Rusli. 1988. Belajar Keterampilan Motorik Pengantar Teori dan Metode. Jakarta: P2LPTK Dirjen Dikti Depdikbud.

Mulyani, D. (2013). Hubungan Kesiapan Belajar Siswa dengan Prestasi Belajar. Jurnal Konselor, 2(1). 
Ni Kadek Novia Purnamasari dkk. 2014. PENERAPAN METODE DEMONSTRASI MELALUI KEGIATAN MELIPAT KERTAS (ORIGAMI) UNTUK MENINGKATKAN PERKEMBANGAN MOTORIK HALUS ANAK. (e-Journal PG-PAUD Universitas Pendidikan Ganesha Jurusan Pendidikan Guru Pendidikan Anak Usia Dini (Volume 2 No 1 Tahun 2014).

Oxendine, J. B. (1984). Psychology Of Motor Learning. Englewood Cliffs. New Jersey: Prentice Hall Inc.

Putri D. Selpia dan Neviyarni. S. (2013). Faktor-faktor Penyebab Rendahnya Prestasi Belajar S iswa. Jurnal Konselor, 2(1).

Rahyubi, Heri. (2012). Teori-teori Belajar dan Aplikasi Pembelajaran Motorik. Bandung: Nusa Media. Sagala, S. ( 2012). Konsep dan Makna Pembelajaran. Bandung: Alfabeta.

Samsudin. (2008). Pembelajaran Motorik di Taman Kanak-kanak. Jakarta: Litera.

Schmidt, Richard, A. 1988. Motor Control And Learning. Second Edition. Illinois: Human Kineticks Publisher Inc.

Syamsu Yusuf LN, 2014. Psikologi Perkembangan Anak \& Remaja. Bandung: PT Remaja Rosdakarya. 